\title{
Language: A Pernicious and Powerful Tool
}

JESSICA PARKER

I will overcome the tradition of silence.

—Anzaldua 59

】

was washing the dishes in our small, shingled home in Sonoma, California, when my mother, who was eyeing me from the dining room, said, "You know, honey, your father and I will still love you if you are gay.” My hands immediately froze. I snapped back in an irritated tone, "Mother, I am not gay. How could you think something like that?" and continued with the nightly routine of scrubbing and rinsing. $\mathbf{\square}$ Throughout my high school years, most of my best friends were gay. Despite this fact, I did not question my own sexuality. I felt emotionally immature compared to my peers who had long-lasting relationships,

and since my romances barely lasted two months, I did not try to untangle my feelings for the girls on whom I had crushes or the boys I thought were cute. Even if my parents had already assumed my sexual orientation as a result of my affiliation with gay friends or my lack of boyfriends, I needed to develop my own understanding of sexuality and become comfortable with my sexual identity.

A year after my mother's vote of confidence in our kitchen, I was a freshman at the University of California at Berkeley. I became intimately involved with a female friend and began to negotiate a gay identity; ultimately, it would take another two years before I would come out to my parents, not to their surprise. Ironically, it was not an easy task. My coming out was a political statement. Although I was ecstatic that my parents accepted me with warm smiles and embraced me with hugs when I came out to them, I was making a conscious decision to become a target of oppression. Society's heterosexual majority, I knew, would not embrace me with those same smiles and hugs. Yet, when I began to witness a handful of my gay and lesbian friends become ostracized by their loved ones after they came out to their families, it became apparent that I should not fear rejection from a homophobic society, when the people I most loved had accepted my sexual orientation unconditionally.

After witnessing the alienation of my friends, I promised myself never to be in the closet- "the identity prison"-regarding my homosexuality. I vowed to overcome the tradition of silence. Unfortunately, my profession as a teacher lends itself to just this dilemma. Coming out to my students differed greatly from confirming my sexual orientation with my supportive loved ones. With 120 new students every fall (I had fewer students than most English teachers because I taught ELL students), I pondered my motivation and the value of revealing my sexual orientation. Why should I expose such a personal issue?

\section{Will students stop using language such as "fag" and "gay" to belittle their peers?}

I taught the 1999-2000 school year at Berkeley High School, in Berkeley, California. My world literature classes discussed and analyzed thematic units: the powerful and the powerless, difference and diversity, social and political injustice, and prejudice. We read 
historical fiction concerning the Japanese-Canadian and Japanese-American internment camps and apartheid in South Africa. We created PowerPoint presentations highlighting the systems in our lives that controlled our actions and related our findings to a Latin American novel by Isabelle Allende. We analyzed gender by reading short stories-written by two female authors from Mexico and Brazilabout women, their families, and coming to terms with illness and boredom. Throughout the school year, we assessed how to bring change to our school and community and make it a more inclusive and appreciative place for people and difference. In this context, which incorporated issues like gender, race, ethnicity, privilege and power, and powerlessness, I felt obligated to overcome the tradition of silence around homosexuality in schools. But, I wondered, how do I weave "coming out" into the curriculum? The answer presented itself during a group project. A student confided in me that two boys could not refrain from claiming "that's so gay" to anything they found displeasing. I decided to come out to my classes the very next day.

From a teacher's perspective, it is essential to have students analyze the language of Shakespeare, the symbolism of Alice Walker, or the metaphors of Sandra Cisneros. From a personal perspective, it is also essential to have students analyze the language of everyday use. So, for my fifth period class, primarily composed of tenth graders, I drew a line on the board and asked a simple question, "What does the word gay mean?" One student responded, "It means a homosexual." "As opposed to heterosexual," I replied, "so gay has to do with one's sexual orientation?" The student nodded. I wrote "sexual orientation" under the line. The students' responses looked like this:

\section{GAY}

$\begin{array}{lll}\text { happy } & \text { sexual } & \text { abnormal } \\ \text { orientation } & \text { sick } \\ & \text { different } \\ & \text { lame } \\ & \text { stupid } \\ & \text { femmie male } \\ & \text { put down } \\ & \text { weird }\end{array}$

I wanted the students to dissect and assess the language they were using (from the right column) to belittle their peers, but lecturing them was futile. I needed to create dialogue and have them reflect upon their own actions and usage.
I asked the class, "Do you think it is wrong for people to use the word gay or fag in a derogatory manner, even though it refers to a group of people and their sexual orientation?" Christine responded, "I don't think it is wrong. I have gay friends. They just need to get used to it." Despite the fact that Christine has gay friends, she still perceives homosexuals as the "other," who have to change to fit the needs of the people in power-heterosexuals. In addition, she marginalizes her gay friends with her homophobic use of language, since she has the ability to define the term "gay" for them.

Sitting directly behind Christine, a student named John added, "You know, you will always insult someone no matter what you say." The nihilistic philosophy the student offered was an impetus for a new teaching strategy. Although we had previously discussed privilege and power in class, Christine and John did not realize they were agents of oppression. I needed to illustrate the connection between our previous discussions and their current use of language. By drawing a comparison with another word, I thought it would clarify how their language was dehumanizing and discriminating against gay and lesbian people. I was going to take a chance.

I then replied to the class:

$$
\begin{aligned}
& \text { The term gay has multiple meanings. The formal } \\
& \text { definition has to do with sexual orientation, but the } \\
& \text { term has also taken on negative connotations. } \\
& \text { What if I took another term that has multiple } \\
& \text { meanings and started using it in a negative way, } \\
& \text { like the word black? Black has multiple meanings. } \\
& \text { What if I went around and instead of saying "That's } \\
& \text { so gay" said "That's so black"? }
\end{aligned}
$$

With uncertain eyes, the students looked at me and said in harmony, "You would be racist." I replied, "Damn right I would be racist." I was using the fact that most of the students at Berkeley High School were intensely aware of racial issues and could easily recognize racism to follow up with a question regarding homophobia, "So why is it different when people use the word gay?" Hands shot in the air. I noticed that Nora was shaking her head. "Why are you shaking your head?" I asked. She replied, "But I don't mean it that way."

I needed to develop strategies to ensure that my curriculum and classroom, my school, and the atmosphere of both environments do not promote homosexuals as the "other." These three students viewed homosexuals as people who had to alter themselves to fit dominant society's view of 
what is acceptable rather than have people alter their use of pernicious terms like gay and fag. Unfortunately, we were short on time. I still needed to explain why I initiated this discussion. I did not have time to direct the conversation into the area of heterosexism and hegemony and begin to deconstruct the prevailing belief that heterosexuality is "the norm" rather than a segment on the continuum of sexuality.

\section{These three students viewed}

\section{homosexuals as people who had}

to alter themselves to fit

\section{dominant society's view of what}

is acceptable rather than have

people alter their use of pernicious

terms like gay and fag.

I continued the discussion by stating, "The reason I wanted to talk about this is because I am gay. I have a partner of two and a half years, and you have actually met her mother. She was the guest speaker during our unit on the Japanese concentration camps in North America, who was interned as a young child." I could tell that most of the students were trying to jog their memory and recall that day. "But, more importantly, the next time someone says, 'Oh, that's so gay,' I want you to say, 'No, Ms. Parker is gay and what you said offends me.' " Although I wanted, initially, to create a dialogue and have students reflect upon their own use of language, I found myself putting words in their mouths. I wanted the students to use me as an example and stand up for me when homophobic labels and terms were used. I felt I was presenting them with a feasible opportunity to make change in their communities. Then Dan replied, "I can't do that Ms. Parker. If I stand up for gay people, then my friends will assume that I am." I nodded in understanding.

Months later, a student e-mailed me about our class discussion, saying, "The conversation made everyone stop and think. We, as individuals, are the only ones who can control how we choose to perceive things in life."

\section{Why should I expose such a personal issue?}

One of my goals as a teacher is to create a curriculum in which the students' education connects with their lives. When I teach literature-for instance, Romeo and Juliet - the themes of teen suicide, gang violence, and parent-child relationships usually resonate with students. This connection is essential. The students can relate to the experiences of the characters and see themselves within the text. If one of my goals as a teacher is to connect literature and history to my students' lives, why can't my history, my personal experiences connect with their lives? Yet, I hear the critiques from the religious right: "Don't bring your personal life into the public schools." "Don't talk about sexual orientation because the parents and/or the church have the right to discuss the subject at home or during mass." and "Don't manipulate the students with your talk about homosexuality." Their rhetoric reminds me that, although it is no longer a crime to be openly gay in the United States, my silence would perpetuate their political agenda rather than assist in dismantling the laws and prejudice that continue to promote and justify discrimination towards homosexuals. Because more and more people are coming out and breaking the silence, a backlash has currently produced more antigay laws than ever before (Eskridge 205), and most gay teachers in the United States do not work in districts that protect their employment rights. The decision to come out to my students, to share and teach my personal history, was something I could not afford to dismiss.

During my eighth period world literature class, which was comprised of tenth through twelfth graders, I opened the discussion with a different question, "Do you hear students using the word gay or fag?" I assumed that my students already knew the formal and colloquial definitions because most of the students had been in the United States for three or more years. Some of the students replied that their friends used the words to belittle other students. One girl raised her hand and asked, "What does the word gay mean anyway?" I was surprised and eager to answer her question. I responded, "It means that a man or a woman loves a person of the same sex." Sushila's hand shot up in the air, "We don't have people like that in my country." She was from India. Alex added, "Maybe in China they did have 
gay people, but now we don't anymore." I was disappointed by the pride in the students' statements: their home countries supposedly did not have any (more) of "those" people. That these students were not fully aware of American cultural references regarding homosexuality but were enculturated to believe that homosexuality was an abnormal deviation reinforced my desire to come out as a gay teacher. Again, it was important for me to be one of "those" people, since I was already an authority figure, and they trusted my guidance as a teacher; I could now give voice to an ignored and/or hidden minority of gays and lesbians that these students did not hear about in their home countries. I told the class, looking at Alex and Sushila, that their countries probably did have gay and lesbian people, and asked if homosexual people would be accepted in their countries. The students agreed that they would not.

The conversation changed when a student named Chen asked, "Is there something physically wrong with gay people?"Anneaka, who had just finished her injustice essay on AIDS in South Africa, replied, "It's not biological. There is nothing wrong with gay people. They should be allowed to love whoever they want to." The student made a direct connection between homosexuality and biological defects; hence, a scientific justification for their social abnormality. Historically, homosexuality was viewed as a mental illness. Scientists claimed there was a pathological condition affecting gays and lesbians and have tried even in the late 1990s to find biological reasons for homosexuality. Yet, Anneaka automatically guided the discussion away from scientific claims to focus on the love between two people.

I came out to this class by stating, "The reason I wanted to discuss this issue is because I am gay." There was a moment of silence and shock. A student responded, "Really?" Amilca then added, "We don't care Ms. Parker, we love you for who you are.” Although Amilca’s stamp of approval was wel- coming, I knew it was just a step in the long process toward visibility and equality. After the school day had ended, a student said to me privately:

I commend you for having such courage and love of education. I think that parts of our class discussion were very ignorant, and I am definitely reminded that homophobia and prejudice run rampant in the world and age in which I live. Even in Berkeley, my classmates have a very closedminded outlook on life.

\section{What real difference will I make by coming out to my students?}

I need to continue coming out to my classes and initiating discussions about homosexuality and homophobia in the hope that one day soon all educators will work for an inclusive and appreciative community that respects all people and all differences and, simultaneously, emphasizes our similarities. Our classroom curriculum is a nexus for this hope. Yet, throughout each semester, I am under pressure to read a number of novels and plays, produce top scores on standardized tests, and align curriculum with the district and state standards. Under these pressures, it is extremely difficult to devote two weeks to a unit on gays and lesbians and adequately discuss the issues presented above. After coming out to my classes, I realized that I needed to integrate gay and lesbian fiction, nonfiction, and history into my curriculum by placing it side-by-side with canonical literature. By implementing thematic units, I am able to weave Like Water for Chocolate with the lesbian-themed movie Fire (an edited version) and the poetry of Jamaica Kincaid; Audre Lorde with Obasan; and The Crucible with Dennis Shepard's appeal to the killers of his son, Matthew (New York Times). Below is a table of the literature and themes I have used and plan to use within the classroom to provide a context of inclusion, where gays and lesbians are not viewed as the "other."

\begin{tabular}{|c|c|c|c|}
\hline & Theme & Making the Connection & Final Assignment \\
\hline LWFC/Fire/Kincaid & Tradition & $\begin{array}{l}\text { Women/obligation/ } \\
\text { gender roles }\end{array}$ & $\begin{array}{l}\text { Tradition essay } \\
\text { (Teacher assigned topic) }\end{array}$ \\
\hline The Crucible/Shepard & Hegemony and difference & $\begin{array}{l}\text { The powerful/influence/ } \\
\text { appreciating difference }\end{array}$ & $\begin{array}{l}\text { A response to The } \\
\text { Crucible (short story, } \\
\text { editorial, spoken word, etc.) }\end{array}$ \\
\hline Lorde/Obasan & Fighting against oppression & $\begin{array}{l}\text { Using your voice to take } \\
\text { a stand }\end{array}$ & $\begin{array}{l}\text { Injustice essay } \\
\text { (student topic) }\end{array}$ \\
\hline
\end{tabular}


When students read Obasan and empathize with the main character, Aunt Emily, and her desire to find justice, and when they read Lorde's appeal to use one's voice to attain this justice, gays and lesbians can be viewed as people who overcome obstacles in life rather than as mere abstractions. When students recognize how women overcome obligation in order to pursue their own desires and needs, the lesbian characters in the movie Fire can be viewed as people who follow their hearts instead of prescribed gender roles. This type of combination allows gays and lesbians to move from the position of "other" to an inclusive setting, where themes are discussed and analyzed, and gays and lesbians are a part of everyday life.

Language is both a pernicious and powerful tool. With 97 percent of students in public high schools regularly hearing homophobic remarks from their peers and 53 percent of students hearing homophobic comments made by school staff, teachers have an obligation to analyze the language of everyday use with their students. With 77 percent of prospective teachers stating that they would not encourage a class discussion on homosexuality and 85 percent opposing gay/lesbian themes in their curriculum, teachers have an obligation to educate other teachers on the impact of homophobia and homophobic language (GLSEN).

After the school year had ended, one of my former students e-mailed me about my coming out and the discussion the class had. The young woman stated:
You touched upon something we needed to hear and needed to discuss. I remember leaving your class feeling enlightened, not in any spiritual way, yet I left feeling hopeful. School could be a place of higher learning. School could be a loving, outreaching, empowering, educating community. Everyone respected you for that, no matter their personal experience or views of the truth you shared.

\section{Works Cited}

Anzaldua, Gloria. Borderlands/La Frontera: The New Mestiza. San Francisco, CA: Aunt Lute, 1987.

Eskridge, William. Gaylaw: Challenging the Apartheid of the Closet. Cambridge, MA: Harvard UP, 1999.

Esquivel, Laura. Like Water for Chocolate. Trans. Carol Christensen and Thomas Christensen. New York: Doubleday, 1992.

Fire. Dir. Deepa Mehta. Zeitgeist, 1998.

GLSEN. Just the Facts. 24 September 1999. <http://www. glsen.org/binary-data/GLSEN_ARTICLES/pdf_file/ 424.pdf>

Janofsky, Michael. "Parents of Gay Obtain Mercy for His Killer." New York Times 4 Nov. 2000: A1+.

Kincaid, Jamaica. At the Bottom of the River. New York: Farrar, Straus \& Giroux, 1983.

Kogawa, Joy. Obasan. Boston, MA: David R. Godine, 1982.

Lorde, Audre. Sister Outsider. Freedom, CA: The Crossing Press, 1984.

Miller, Arthur. The Crucible: The Text and Criticism. New York: Penguin, 1996.

Shakespeare, William. Romeo and Juliet. New York: Penguin, 1992.

JEssiCA PARKER teaches at Berkeley High School, Berkeley, California.

APPENDIX

\section{Resources}

Gay-Straight Alliance Network (GSA) offers school based support groups, which provide students with a place to meet and talk about issues relating to sexual orientation and also provide support for teachers to implement activities and integrate gay and lesbian issues into the curriculum (www.gsa.network.org).

Gay and Lesbian Alliance Against Defamation (GLAAD) analyzes textbooks and mass media for anti-gay bias and advocates for fair treatment of sexual minorities in media (www.glaad.org).

Gay, Lesbian and Straight Education Network (GLSEN) provides education, support, and advocacy on the issue of homophobia in K-12 schools (www.glsen.org).

OutProud! The National Coalition for Gay, Lesbian, Bisexual, and Transgender Youth provides advocacy, resources, and support for LGB youth and agencies that work with them (www.outproud.org).

Parents, Families, and Friends of Lesbians and Gays (PFLAG) provides support, education, and advocacy (www.pflag.org). 